\title{
ICOR Analysis of Gorontalo Province
}

\author{
Kalzum R. Jumiyanti ${ }^{1^{*}}$, Wahyudin Hasan ${ }^{2}$ \\ ${ }^{1,2}$ Universitas Gorontalo
}

\section{Article Information}

History of article:

Received April 2021

Approved September 2021

Published October 2020

\begin{abstract}
Investment plays an important role as one of the regional economic drivers. Likewise, a various development success is determined by the quality of planning and accurate data. In general, the development planning is highly specified by an ability to provide financing sources scenario where one of which is investment as it is impactful in increasing economic growth rate and community welfare level intended. This research aims at determining ICOR value and investment needs estimate in Gorontalo Province and at determining sectors with a higher or lower capital productivity in Gorontalo Province. The research employs ICOR analysis to measure certain amount as a comparison between growth of capital (investment) with production. Through these indicators, the economic development planners can determine investments needed to increase the economy in compliance with the predetermined target. The research findings reveal that: 1) ICOR value from 2018 to 2020 is 0.29 on average and it is impacted by annual capital change $(\Delta K)$ and output change $(\triangle Y), 2)$ food industry sector in Gorontalo Province indicates a sufficiently low value of ICOR, and it is good due to the economic runs efficiently. Meanwhile, the chemistry and pharmacy industry sector shows massive capital productivity where a higher value of ICOR indicates capital-intensive technology use. Also, an ICOR-based sectoral investment projection signifies that the researchers set top three of future leading sectors in 2025 for investment projection in Gorontalo. They are food and plantation crops; trade and repair; and construction, 3) a stay-at-home policy urged by the government during the covid-19 pandemic has led to a significant change in community's consumption style for basic needs such as water, electricity, gas, food, and medication.
\end{abstract}

Keywords: ICOR; Economic Growth; Investment Projection

JEL Classification Code: O47, C39, E22

(C) 2021 MediaTrend

Author correspondence:

E-mail: yanti.kalzum@gmail.com

DOI: http://dx.doi.org/10.21107/mediatrend.v16i2.10305

2460-7649 @ 2021 MediaTrend. All rights reserved. 


\section{INTRODUCTION}

One of the determinants of the success of economic growth of LDCs (Least Development Countries) is capital resources. Capital resources or investment accumulation are carried out to increase production capacity. Consequently, the production will also increase and will have a direct impact on economic growth.

The increase in economic growth is caused by the increase in production factors, including: population growth that will increase the workforce, investment that will increase capital goods, and technological advances in the means of production that will accelerate the increase in production capacity. Therefore, it is undeniable that investment is one of the drivers of regional economic development.

According to the Lewis model (cited in Halim, 2004), the core of the problem in economic development lies in the capital accumulation, where the process of understanding a community that previously saved and invested $4 \%$ or $5 \%$ of its national income or less turns into an economy where the savings become approx. $12 \%$ to $15 \%$ of national income or more.

A region with varying development success is determined by the quality of planning and accurate data. According to Irawan (2010), the formulation of development planning is basically determined by the ability to provide financing sources scenario, one of which is investment in order to increase the economic growth rate and the community welfare level intended.

Munifah (2019) appends that the determination of economic growth targets has been determined in each region for economic development planning. One of them comes from the investment, so the target of achieving economic growth requires an indicator related to investment. The required indicator is the Incremental Capital Output Ratio (ICOR) or additional output and capital. The determinant in the formation of economic output in a region is the capital stock. Walters (2016) states that it is appropriate to use ICOR for economic development planning as it can predict investment needs.

Since early 2020 , Indonesia is one of the hardest-hit countries by the COVID-19 pandemic. The Indonesian Investment Coordinating Board (BKPM) projects that Indonesia's investment in 2020 will reach IDR 886 trillion. However, the emergence of Covid-19 made BKPM cut its investment growth target to IDR 855.6 trillion by a condition that Covid-19 ended in May 2020. In fact, the pandemic keeps on rising and has forced BKPM to re-cut its investment projection to IDR 817.2 trillion, assuming Covid-19 will end in July 2020. On the other hand, the realization of investment from the initial projection of IDR 886.1 trillion until the first quarter has recorded an inward investment of IDR 210.7 trillion. This value includes PMDN (Penanaman Modal Dalam Negeri or Domestic Investment) of IDR 112.7 trillion or 53.5\% and PMA (Penanaman Modal Asing or Foreign Investment) of IDR 98 trillion or $46.5 \%$. Throughout the first quarter, the investment manages to absorb 303.085 Indonesian Migrant Workers (TKI) (Kompas. com, 2020).

The earlier phenomenon is the main reason for conducting research related to investment issues in the midst of the COVID-19 pandemic, more specifically in Gorontalo Province. The COVID-19 pandemic has resulted in consumer purchase intention decreasing drastically and directly impacting the decline in investment in Gorontalo Province. Moreover, such the effect has challenged the provincial government to be able to rise from the economic downturn. One of the successes of the region to increase competitiveness in investment depends on the ability of region to formulate policies related to investment and business and improvement in the services quality to the community. It is also important to pay attention to con- 
ducive macro economy, human resources development, and infrastructure to attract investors. Eventually, this condition is believed to be able to move the private sector to participate in driving the economy.

The relationship between investment and Harrod-Domar theory is very close in the model of economic growth. According to Susilowati et al (2012), Harroddomar's theory basically analyzes the condition needed so that the national economy is able to grow steadily in the future. More importantly, the role of capital formation in an effort to create economic growth is also pivotal. The condition that must be met is that in the long term, the production capacity, which has increased from year to year as a result of capital formation in the previous year, must be fully utilized. The relationship between capital formation and output growth is reflected in the macroeconomic indicator known as ICOR (Incremental Capital Output Ratio). This indicator shows the amount of additional new capital needed to increase one unit of output (or value added). Also, according to Setiyanto (2015), the calculation of ICOR is crucial and useful to obtain information that can be used as a basis for calculating the amount of investment is needed to achieve the desired economic growth.

This study attempts to dig up information about investment potential and investment climate in Gorontalo Province, which is indispensable as a material for consideration in making decision related to location for investment. Additionally, the study aims at responding to the following problems: 1) how to study and estimate ICOR and the estimated amount of investment needs in Gorontalo Province; 2) which sectors have higher or lower capital productivity in Gorontalo Province.

\section{METHODOLOGY} Formula Applied

According to Dariyanto \& Hafizrianda (2010), ICOR is the most important and impactful concept for the economic development planning of Gorontalo Province. The impact appears when examining the consistency between regional income growth target and the additional capital that may be accrued from ongoing domestic saving. In estimating the financial growth, it is necessary to estimate the volume of investment required to achieve a certain output target.

Therefore, the estimated future investment is highly determined by the ICOR, so that the accuracy in measuring ICOR is one of the main requirements that must be met when development planners aspire to estimate investment needs. Errors in calculating ICOR will cause investment planning to be incorrect, which ultimately reduces accuracy in predicting regional economic growth. For this reason, a more in-depth ICOR analysis is needed that can meet the CAP (Comprehensive, Accurate, and Predictable) criteria, which contains the following meanings: (1) comprehensive or detailed by sector, region and field of development, (2) accurate and thorough in conformity with each characteristic of the return on investment, and (3) predictable that can predict investment and regional economic growth with a high level of accuracy. The formulation to calculate ICOR employs the following formula (Dariyanto \& Hafizrianda, 2010):

$$
K_{t}=\frac{I}{\Delta Y}
$$

\section{Analysis Method: Annual ICOR Esti- mate}

\section{a. ICOR without Time Lag}

According to Artis, Syaparuddin, \& Nurhayati (2015), if the investment made in year $t$ is assumed to generate income (output) in year $t$ or the year concerned, then the ICOR estimate obtained through this approach is ICOR without a time lag which can be calculated by the following 
formula:

$k_{t}=\frac{I_{i t}}{\Delta Y_{i t}}=\frac{\frac{I_{i t}}{Y_{i t-1}} x 100}{g_{i t}}$

where kt is ICOR in year $t$ for activity $i$, lit is Investment in year t for activity i, Yit-1 is regional income in $t$ for activity $i$, git is growth rate of activity $i$ in year $t$

\section{b. ICOR with One-Year Time Lag}

ICOR estimates with one-year time lag imply that investments made in year $\mathrm{t}-1$ will only provide additional returns in year $t$, or in other words, investments made in year $\mathrm{t}$ will provide results in year $\mathrm{t}+1$ (Artis et al., 2015). The ICOR estimate with oneyear time lag can be calculated by the following formula:

$$
k_{t}=\frac{I_{i t-1}}{\Delta Y_{i t}}=\frac{\frac{I_{i t-1}}{Y_{i t-1}} x 100}{g_{i t}}
$$

where kit is ICOR in year $t$ for activity $i$, lit-1 is Investment in year t-1 for activity i, Yit-1 is Regional income in year $\mathrm{t}-1$ for activity $i$, git is Growth rate of for activity $i$ in year $t$

\section{c.ICOR with More than One-YearTime Lag} In certain activities, the time lag between the investment and additional return obtained as a result of the investment can be more than one year (Artis et al., 2015). If the investment period for year $\mathrm{t}-2$ will provide additional regional income in year $t$, the ICOR calculation is carried out by the following formula:

$$
k_{t}=\frac{I_{i t-2}}{\Delta Y_{i t}}=\frac{\frac{I_{i t-2}}{Y_{i t-1}} x 100}{g_{i t}}
$$

In the meantime, if the additional return earned in the next three years, thus ICOR is calculated by the following formula:

$k_{t}=\frac{I_{i t-3}}{\Delta Y_{i t}}=\frac{\frac{I_{i t-3}}{Y_{i t-1}} x 100}{g_{i t}}$

where kit is ICOR in year $t$ for activity $\mathrm{i}$, lit2 is Investment in year t-2 for activity i, lit-3 is Investment in year $\mathrm{t}-3$ for activity $\mathrm{i}$, Yit-1 is Regional income in year $t-1$ for activity $i$, git is Growth rate of activity $i$ in year $t$

\section{d. Average ICOR}

The average ICOR estimate is inaccurate if it is based on the average ICOR per year, due to there may be a bias in the numbers that may occur in certain years. To overcome this, the calculation of the average ICOR should be based on the development of investment and cumulative additional return over a certain period of time. As with the annual ICOR, the calculation of the average ICOR can also be distinguished based on the time lag (Artis et al., 2015). However, the common formula for this average ICOR is as follows:

$$
\overline{k_{t}}=\frac{\sum_{t=0}^{t=n} I_{i t-n}}{\Delta Y_{i t}}
$$

where, $\mathrm{k}$ is average ICOR, I is Investment $\Delta \mathrm{Y}$ is additional return (regional income), $i$ is activity $i, t$ is year $t, h$ is time lag used where $\mathrm{h}>1$

The higher the ICOR, the higher level of economic leakage. Conversely, if the ICOR is low, it indicates that the economy is running at a high level of efficiency so that the leakage is low. 
Type and Source of Data and Its Limitation

The data used in preparing ICOR are from various sources, including APBD (Regional Budget) financial statement, reports from agencies or companies, BKPM (Indonesian Investment Coordinating Board), Bank Indonesia, and publications on survey and census results published by Statistics of Districts/City in Gorontalo and Statistics of Gorontalo Province. Total investment is calculated from the amount of Gross Regional Domestic Product (GRDP) used for capital formation and stock change. This value is also used as total control of the overall ICOR value. It is known that the concept of output used in the preparation of ICOR is Gross Value Added (GVA). The data regarding the increase in GVA are obtained from the published results of GRDP calculation. Considering the limitation of existing data, the mentioned data cannot simply be used in calculating ICOR. Therefore, it requires some adjustments and refinements to the data, particularly the extreme data. In addition, the adjustments and refinements are performed due to the output and investment limit in the ICOR concept are slightly different from the standard limit.

\section{RESULTS AND DISCUSSION \\ Finding}

1. General Outline of Gorontalo Province's Economy

According to Statistics of Gorontalo Province (2020), the land area of Gorontalo Province is $11.257,07 \mathrm{~km} 2$, most of which are on the mainland of Gorontalo, and a small portion are located on several small islands in Boalemo District, Pohuwato District, and Gorontalo Utara District. Based on the area by districts/city in Gorontalo Province, the largest area is Pohuwato District with an area of 4.244,31 $\mathrm{km} 2$ or $37.7 \%$ of the total area of Gorontalo, followed by Bone Bolango District with an area of $1.984,31 \mathrm{~km} 2$ or $17.63 \%$,
Gorontalo District with an area of $1.750,83$ $\mathrm{km} 2$ or $16.55 \%$, whereas the smallest area is Gorontalo City with an area of 79,59 $\mathrm{km} 2$ or $0.71 \%$ of the total area of Gorontalo Province. In 2019, the Gross Regional Domestic Product of Gorontalo Province at current prices was $41.150,59$ billion rupiahs and based on 2010 constant prices, and the 2019 GRDP was 28.432,87 (billion). The 2010 Constant Prices economic growth rate in 2017 in Gorontalo Province was $6.73 \%$ where it signified a slowing down compared to the previous year, which was $6.5 \%$, which then decreased in 2019 to $6.41 \%$ (Statistics of Gorontalo Province, 2020).

Based on Current Prices (ADHB) in 2019, agriculture, forestry, and fisheries sectors are the main contributors with a role reaching $38.93 \%$, followed by wholesale and retail trade sector; repair of cars and motorcycles by $12.42 \%$ and construction sector by $10.67 \%$ (Statistics of Gorontalo Province, 2020). To notice an economic productivity (by ignoring inflation), GRDP at Constant Prices (ADHK) is used. Based on the constant prices in 2010, Gorontalo's GRDP in 2019 was IDR 28.432,87 (billion). The water supply, waste management, and recycling sectors experienced the highest growth at $13.61 \%$, followed by wholesale and retail trade and repair of car and motorcycle sectors at $11.88 \%$ and manufacturing industry sector at $11.62 \%$. Overall, Gorontalo's economy in 2019 grew by $6.41 \%$, and it decreases compared to the previous year.

2. Population Growth and Employment

Based on the 2010-2020 Population Projection, the total population of Gorontalo Province in 2019 was 1.202,63 thousand people, where Gorontalo was ranked 3rd with the least population in Indonesia. In 2019, the number of people aged 15 years and over, including the workforce was 585.896 people with a labor force participation rate of $66.83 \%$. Of the total workforce, the number of employed people is 
Table 1.

Recapitulation of Investment and GRDP ADHK 2010 of Gorontalo Province (in Billion Rupiah)

\begin{tabular}{|c|c|c|c|c|c|c|}
\hline \multirow[t]{2}{*}{ Sector } & \multicolumn{3}{|c|}{ Investment } & \multicolumn{3}{|c|}{ GRDP } \\
\hline & 2018 & 2019 & 2020 & 2018 & 2019 & 2020 \\
\hline \multicolumn{7}{|l|}{ Primary Sector } \\
\hline 1. Crops and Plantation & 894 & 456 & 1.856 & 6918.38 & 7303.53 & 7143.78 \\
\hline 2. Livestock & 3 & 13 & 15 & 710.31 & 767.42 & 764.18 \\
\hline 3. Forestry & 32 & 4 & 2 & 166.58 & 170.49 & 167.21 \\
\hline 4. Fishery & 26 & 171 & 16 & 2223.78 & 2412.32 & 2407.05 \\
\hline 5. Minir & 1.571 & 1.438 & 116 & 318.15 & 333.86 & 332.18 \\
\hline \multicolumn{7}{|l|}{ Secondary Sector } \\
\hline 6. Food Industry & 303 & 282 & 280 & 671.34 & 771.37 & 798.70 \\
\hline 7. Textile Industry & 1 & 4 & & 26.29 & 28.10 & 25.54 \\
\hline $\begin{array}{l}\text { 8. Leather Goods and } \\
\text { Footwear Industry }\end{array}$ & - & - & 4 & & & \\
\hline 9. Wood Industry & 225 & 27 & 4 & 107.18 & 116.02 & 114.69 \\
\hline $\begin{array}{l}\text { 10. Paper and Printing } \\
\text { Industry }\end{array}$ & 2 & 3 & 3 & 18.63 & 19.28 & 18.66 \\
\hline $\begin{array}{l}\text { 11. Chemical and } \\
\text { Pharmaceutical } \\
\text { Industry }\end{array}$ & 99 & 3 & 2 & 0.55 & 0.56 & 0.56 \\
\hline $\begin{array}{l}\text { 12. Rubber and Plastic } \\
\text { Industry }\end{array}$ & - & 2 & - & 1.18 & 1.22 & 1.22 \\
\hline $\begin{array}{l}\text { 13. Nonmetallic Mineral } \\
\text { Industry }\end{array}$ & - & 1 & - & 83.60 & 89.11 & 88.95 \\
\hline $\begin{array}{l}\text { 14. Metal, Machinery, and } \\
\text { Electronics Industry }\end{array}$ & - & 7 & 3 & 15.59 & 14.78 & 14.21 \\
\hline $\begin{array}{l}\text { 15. Medical Precision, } \\
\text { Optical, and Watch } \\
\text { Instruments Industry }\end{array}$ & - & - & - & - & - & \\
\hline $\begin{array}{l}\text { 16. Motorcycle and Other } \\
\text { Transportation } \\
\text { Industry }\end{array}$ & - & 2 & 5 & 7.29 & 7.29 & 7.13 \\
\hline 17. Other Industries & 1.415 & 568 & 515 & 108.05 & 112.12 & 103.23 \\
\hline \multicolumn{7}{|l|}{ Tertiary Sector } \\
\hline $\begin{array}{l}\text { 18. Electricity, Gas, and } \\
\text { Water }\end{array}$ & 669 & 1.568 & 741 & 36.46 & 40.38 & 43.22 \\
\hline 19. Cor & 117 & & 1.051 & 4 & 06 & 059.83 \\
\hline 20. Tra & 418 & 1.0 & 7 & 3017.51 & 3372.24 & 3325.70 \\
\hline 21. Hotel and Restaurant & 66 & 116 & 195 & 625.46 & 666.95 & 659.74 \\
\hline $\begin{array}{l}\text { 22. Transportation, } \\
\text { Warehouse, and } \\
\text { Communication }\end{array}$ & 44 & 345 & 208 & 2417.36 & 2556.98 & 2548.55 \\
\hline $\begin{array}{l}\text { 23. Housing, Industrial } \\
\text { Estate, and Office } \\
\text { Building }\end{array}$ & 68 & 68 & 854 & 2559.18 & 2657.60 & 2661.86 \\
\hline 24. Education & - & 5 & - & 1155.24 & 1262.79 & 1328.11 \\
\hline 25. Other Services & & & & 2538.51 & 2659.97 & 2810.01 \\
\hline Total & 7.448 & 8.312 & 8.227 & 26719.27 & 28428.44 & 28422.29 \\
\hline
\end{tabular}

Source of Data : (Bank Indonesia, 2021) ; (Indonesian Investment Coordinating Board of Gorontalo Province) ; (Statistics of Gorontalo Province, 2021) 
562.087, while the unemployed are 23.809 people, with an open unemployment rate of $4.06 \%$ (Statistics of Gorontalo Province, 2020).

\section{Investment and ICOR}

Investment is the entire expenditure of sources of funds to obtain capital goods (capital expenditure). As a factor of production, investment is a pivotal factor in increasing regional GRDP. In accordance with the growth theory by Harrod-Domar, investment has a key role in economic growth to create income and to increase production capacity of the economy by increasing the capital stock. Meanwhile, economic growth is caused by capital goods, labor, and changes in the productivity of these factors of production. An increase in investment (capital goods) can affect economic growth, in which an increase in investment will increase economic growth, and a decrease in investment will decrease economic growth (Bhinadi, 2003). In addition, economic growth is directly related to foreign direct investment inflow. Good economic growth will provide a positive signal for investment inflow. This means that private investment is the engine of economic growth (Kunle, A., S.O. \& Oluwafolakemi, 2014). According to Sukirno (2010), investment activities allow a community to continuously improve economic activities and job opportunities, increase national income and increase the level of community welfare. The decline in investment will cause the level of national income to fall below the capacity of national income. An increase in investment into certain region will result in an increase in economic growth. The following is the investment data for Gorontalo Province during 2018-2020 in table 1.
The data above shows that in 2018, the total investment was IDR 7.448.000.000.000 while in 2019, the investment increased to IDR 8.312.000.000.000. The increase in investment during the period of 2018 - 2019 was IDR 864.000.000.000. In 2020, the investment was IDR 8.227.000.000.000 where it indicated a reduction compared to the previous year (2019-2020), which was IDR 85.000.000.000,--

In reference to the previous data, the ICOR value can be determined as follows in table 2.

The calculation of ICOR of Gorontalo Province above is an approach to investment and GRDP data based on constant prices in 2010. According to Soemitro (cited in Mahmud, 2008), the high and low ICOR reflects the high and low economic cost of aggregative investment. This is also supported by the statement of Artis et al., (2015) that the large role of consumption in the economy causes the relatively small role of investment value on economic growth in Gorontalo Province. Referring to the earlier ICOR value, the sector that contributes the most is the Chemical and Pharmaceutical Industry and followed by other sectors that also show a large contribution compared to others.

\section{Sectoral ICOR of Gorontalo Province}

The table below is presented to disclose ICOR value without a time lag, ICOR value with a one-year time lag, ICOR value with more than one-year time lag, and average ICOR value in table 3.

Based on the time lag specified above, a higher ICOR value indicates that the sector or economy has a very high level of economic leakage. Conversely,

Table 2.

ICOR of Gorontalo Province

\begin{tabular}{lccc}
\hline Year & $\mathbf{2 0 1 8}$ & $\mathbf{2 0 1 9}$ & $\mathbf{2 0 2 0}$ \\
\hline ICOR & 0.28 & 0.29 & 0.29 \\
\hline
\end{tabular}


Table 3.

Sectoral ICOR of Gorontalo Province

\begin{tabular}{|c|c|c|c|c|c|}
\hline Sector & COR & $g^{*}$ & $\mathrm{ICOR}_{(\mathrm{t})}$ & $\mathrm{ICOR}_{(\mathrm{t}-1)}$ & $\mathrm{ICOR}_{(\mathrm{t}-2)}$ \\
\hline \multicolumn{6}{|l|}{ Primary Sector } \\
\hline 1. Crops and Plantation & 0.26 & -2.24 & -11.36 & -2.79 & -5.47 \\
\hline 2. Livestock & 0.02 & -0.42 & -4.72 & -3.96 & -0.98 \\
\hline 3. Forestry & 0.01 & -1.96 & $-0,46$ & -1.14 & -9.70 \\
\hline 4. Fishery & 0.01 & -0.22 & -3.03 & -32.26 & -5.01 \\
\hline 5. Mining & 0.35 & -0.50 & -68.71 & -853.84 & -932.34 \\
\hline \multicolumn{6}{|l|}{ Secondary Sector } \\
\hline 6. Food Industry & 0.35 & 3.42 & 10.63 & 10.69 & 11.48 \\
\hline 7. Textile Industry & 0.01 & -10.03 & -0.11 & -1.59 & -0.23 \\
\hline 8. Leather Goods and Footwear Industry & - & - & - & - & - \\
\hline 9. Wood Industry & 0.03 & -1.16 & -2.84 & -20.04 & -167.11 \\
\hline 10. Paper and Printing Industry & 0.17 & -3.32 & -4.91 & -5.38 & -3.20 \\
\hline 11. Chemical and Pharmaceutical Industry & 4.42 & 0.49 & 911.30 & 966.66 & 36346.82 \\
\hline 12. Rubber and Plastic Industry & 0.06 & 0.08 & 78.19 & 1636.60 & 0.00 \\
\hline 13. Nonmetallic Mineral Industry & 0.00 & -0.18 & -2.34 & -7.61 & -0.32 \\
\hline $\begin{array}{l}\text { 14. Metal, Machinery, and Electronics } \\
\text { Industry }\end{array}$ & 0.24 & -4.06 & -5.71 & -10.89 & -0.04 \\
\hline $\begin{array}{l}\text { 15. Medical Precision, Optical, and Watch } \\
\text { Instruments Industry }\end{array}$ & - & - & - & & \\
\hline $\begin{array}{l}\text { 16. Motorcycle and Other Transportation } \\
\text { Industry }\end{array}$ & 0.70 & -2.19 & -31.47 & -12.39 & -0.28 \\
\hline 17. Other Industries & 4.99 & -8.61 & -53.38 & -58.82 & -146.61 \\
\hline \multicolumn{6}{|l|}{ Tertiary Sector } \\
\hline 18. Electricity, Gas, and Water & 17.14 & 6.56 & 279.63 & 591.87 & 252.58 \\
\hline 19. Construction & 0.34 & -0.17 & -200.63 & -62.14 & -22.38 \\
\hline 20. Trade and Repair & 0.24 & -1.40 & -16.70 & -21.99 & -8.86 \\
\hline 21. Hotel and Restaurant & 0.30 & -1.09 & -26.68 & -15.84 & -9.11 \\
\hline $\begin{array}{l}\text { 22. Transportation, Warehouse, and } \\
\text { Communication }\end{array}$ & 0.08 & -0.33 & -24.63 & -40.73 & -5.24 \\
\hline $\begin{array}{l}\text { 23. Housing, Industrial Estate, and Office } \\
\text { Building }\end{array}$ & 0.32 & 0.12 & 262.45 & 21.00 & 20.97 \\
\hline 24. Education & 0.00 & 4.92 & 0.00 & 0.08 & 0.00 \\
\hline 25. Other Services & 0.56 & 5.34 & 11.03 & 13.15 & 10.51 \\
\hline
\end{tabular}

if the ICOR value is low, the economy is running at a high level of efficiency, so that economic leakage will be low too. The previous data are supported by research (Susilowati et al., 2012) which states that the ICOR value $<1$ signifying an efficient investment.

In terms of economic growth $\left(g^{*}\right)$, the economic condition in 2020 was not so good, as a decline in growth in various sectors has been recorded. Also, table 3 above reveals that that out of the 25 investment sectors, only 7 sectors show positive economic growth, whereas the rest are negative. The seven sectors include: Food Industry, Chemical and Pharmaceutical Industry, Rubber and Plastic Industry, Electricity, Gas and Water, Housing, Industrial Estate and Office Building, Education, and other services.

\section{Projection of ICOR}

To increase investment in Gorontalo Province, both public investment and private investment, it is necessary to make an investment projection based on the investment value in 2020 , where trend moment analysis is employed for economic growth projection $(\mathrm{g})$. The trend moment 
Table 4.

Sectoral Investment Needs Estimate based on ICOR

\begin{tabular}{|c|c|c|c|c|c|}
\hline Sector & $\mathrm{I}_{2020}$ & ICOR & $\mathbf{g}^{\mathbf{\Lambda}_{2025}}$ & $\Delta \mathbf{I}_{2025}$ & $I^{\wedge} \boldsymbol{\Lambda}_{2025}$ \\
\hline (a) & (b) & (c) & (d) & $(e)=(c) x(d)$ & $(f)=(e) x(b)+(b)$ \\
\hline 1. Crops and Plantation & 1.856 & -11.36 & 3.30 & 4.4542 & 34445.81 \\
\hline 2. Livestock & 15 & -4.72 & 3.20 & 4.2882 & 4042.15 \\
\hline 3. Forestry & 2 & $-0,46$ & 3.30 & 4.4536 & 912.88 \\
\hline 4. Fishery & 16 & -3.03 & 3.10 & 4.1083 & 12297.03 \\
\hline 5. Mining & 116 & -68.71 & 3.15 & 4.2017 & 1728.90 \\
\hline 6. Food Industry & 280 & 3.42 & 2.76 & 3.5586 & 3461.95 \\
\hline 7. Textile Industry & - & -10.03 & 4.00 & 5.6641 & 171.18 \\
\hline 8. Leather Goods and Footwear Industry & 4 & - & - & - & - \\
\hline 9. Wood Industry & 4 & -1.16 & 3.18 & 4.2411 & 602.09 \\
\hline 10. Paper and Printing Industry & 3 & -3.32 & 3.41 & 4.6404 & 106.26 \\
\hline 11. Chemical and Pharmaceutical Industry & 2 & 0.49 & 3.11 & 4.1416 & 3.89 \\
\hline 12. Rubber and Plastic Industry & - & 0.08 & 3.09 & 4.1035 & 7.21 \\
\hline 13. Nonmetallic Mineral Industry & - & -0.18 & 3.11 & 4. 1317 & 457.48 \\
\hline $\begin{array}{l}\text { 14. Metal, Machinery, and Electronics } \\
\text { Industry }\end{array}$ & 3 & -4.06 & 3,58 & 4.9258 & 85.19 \\
\hline $\begin{array}{l}\text { 15. Medical Precision, Optical, and Watch } \\
\text { Instruments Industry }\end{array}$ & - & - & - & - & - \\
\hline $\begin{array}{l}\text { 16. Motorcycle and Other Transportation } \\
\text { Industry }\end{array}$ & 5 & -2.19 & 3.35 & 4.5329 & 40.46 \\
\hline 17. Other Industries & 515 & -8.61 & 3.90 & 5.4850 & 670,47 \\
\hline 18. Electricity, Gas, and Water & 741 & 6.56 & 2.56 & 3.2376 & 184.13 \\
\hline 19. Construction & 1.051 & -0.17 & 3.15 & 4.1965 & 15901.42 \\
\hline 20. Trade and Repair & 788 & -1.40 & 3.17 & 4.2233 & 17372.07 \\
\hline 21. Hotel and Restaurant & 195 & -1.09 & 3.19 & 4.2574 & 3469.49 \\
\hline $\begin{array}{l}\text { 22. Transportation, Warehouse, and } \\
\text { Communication }\end{array}$ & 208 & -0.33 & 3.13 & 4.1646 & 13163.13 \\
\hline $\begin{array}{l}\text { 23. Housing, Industrial Estate, and Office } \\
\text { Building }\end{array}$ & 854 & 0.12 & 3.12 & 4.1442 & 13688.93 \\
\hline 24. Education & & 4.92 & 2.69 & 3.4443 & 5903.51 \\
\hline 25. Other Services & 1.567 & 5.34 & 2.86 & 3.7183 & 20769.12 \\
\hline Total & 8.227 & & 2.94 & 3.9327 & 149664.75 \\
\hline
\end{tabular}

method is an analytical method used for predicting purposes based on historical data (time series) by forming an equation $Y=a+b X$.

The data above signify the investment projection of Gorontalo Province for 2025. Dariyanto \& Hafizrianda (2010) state that the higher ICOR indicates that a sector or economy has a very high level of economic leakage. Conversely, if the ICOR is low, the economy is running with a high level of efficiency, so that economic leakage is low too. In other words, a lower ICOR indicates the technology used in the sector is labor-intensive, while a higher
ICOR indicates the use of capital-intensive technology.

\section{Discussion}

1. ICOR of Gorontalo Province

Table 2. shows the condition of average ICOR value from 2018 to 2020 , which showing the value of 0.29 , and it is impacted by changes in capital $(\Delta \mathrm{K})$ and changes in output $(\Delta Y)$ in each year. During the COVID-19 Pandemic in 2020, there was a decline in the value of capital and output.

Meanwhile, table 3 provides an outline of the sectoral ICOR condition of 
Gorontalo Province. Of the 17 sectors that became output, only a few sectors show positive values, whereas the rest are negative, meaning that no economic growth in these sectors is recorded. Sectors showing positive growth (g) in 2020 are: Food Industry; Chemical and Pharmaceutical Industry; Rubber and Plastic Industry; Electricity, Gas and Water; Housing, Industrial Estate and Office Building; Education; and Other Services.

2. Investment Needs Estimate and Sector with High/Low Productivity

Based on table 3 , it is identified that the sector that has high productivity is the food industry which shows a good level of capital productivity compared to other sectors. For ICOR with one-year time lag (lag 1 ) is 10.69 , and in conformity with the figure, it is visible that to increase output by IDR 1.000.000, an investment of IDR 10.686.500 is needed. The figure can also be interpreted as follows: an investment increase by IDR 10.686 .500 will encourage an increase in output by IDR 1.000 .000 (ADHK 2010). The food industry sector in Gorontalo Province has a sufficiently low ICOR value compared to other sectors, and it is in accordance with the theory according to Dariyanto \& Hafizrianda (2010), where a low ICOR value is good due to the economy runs with a high level of efficiency so that economic leakage is low. In other words, the lower the ICOR, the greater the efficiency and productivity of the invested investment so that the more efficient and productive the investment will lead to economic growth (Kuntara, 2016).

The sector with low productivity is the chemical and pharmaceutical industries. Based on table 3, the chemical and pharmaceutical industry owns massive capital productivity compared to other sectors, the ICOR(t-2) value is 36346.82 , and the figure can be interpreted as follows: to increase output by IDR 1.000 .000 in the next two years, an investment of IDR 36.346.820.000 is needed this year. Ac- cording to Dariyanto \& Hafizrianda (2010), this shows that the higher ICOR condition indicates that a sector or economy has a very high level of economic leakage.

The projections of investment needs can be noticed in table 4 that is a sectoral investment projection based on ICOR, where the researchers rank top three sectors that will become leading sectors in $\mathbf{2 0 2 5}$ for Gorontalo investment projection and they are food and plantation crops; trade and repair; and construction. The following is the analysis:

An investment estimate for Food and Plantation Crops sector:

$\mathrm{I}^{2025}=\left(\right.$ ICOR $\left.\times \mathrm{g}^{2025}+1\right) \times \mathrm{I}_{2020}$

$=((-11.36) \times 3.30+1) \times 1.856$

$=34445.81$

It is interpretable that based on the estimation, the income growth of the food and plantation crops sector in 2025 is $3.30 \%$, and the ICOR is -11.36 , then to achieve this income growth, an additional $4.45 \%$ of investment is needed or IDR 34445.81 in rupiah. Overall, it is obvious that in order to achieve regional economic growth of $2.94 \%$ in 2025 (see total line), investment growth of $3.9327 \%$ is needed from 2020 to 2025 , or the additional regional investment needed is IDR 149664.75 in rupiah.

3. ICOR during Covid-19 Pandemic

According to BKPM Indonesia (2020), the COVID-19 pandemic that has occurred since March 2020 has had a considerable impact on almost all countries in the world, including Indonesia and Gorontalo Province as a part of the country. The negative impact strikes not only in one area of investment but also in almost all existing activities. This is due to a policy where the central government urges the local government to carry out lockdown in each region, which eventually impacts economic activity. The lockdown has forced all citizens to stay at home/work from home for office workers. Meanwhile, the entrepreneurs choose to reduce production and even are forced 
to lay off their employees. It is noticeable that in table 3 column $\left(\mathrm{g}^{*}\right)$, the economic growth occurs only in 7 sectors, namely; electricity, gas and water $(6.65 \%)$; other services (5.54\%); education $(4.92 \%)$; food industry $(3.42 \%)$; chemical and pharmaceutical industry $(0.49 \%)$; housing, industrial estate and office building $(0.12 \%)$ and the rubber and plastic industry $(0.08 \%)$. In addition, they show negative values, which in other words, they do not show any economic growth.

In consideration of government's policy to stay at home during the COVID-19 pandemic, the needs for household basics such as water, electricity, gas and even food and medication have greatly changed people's consumption style. A study conducted by Hapsari, Astuti, \& Praswati (2020) underpins the previous data by stating that there have been highly significant changes, especially in the community's dietary patterns and also medication according to research conducted by Dewati \& Saputro (2020). In the meantime, a study related to the economic growth in the electricity and gas sector has been completed by Widyastuti \& Nugroho (2020) and declares that the COVID-19 pandemic had an impact on decreasing prices and production of oil and gas, including the cessation of upstream activities and reduction of refinery activities. However, the oil and gas industry plays an important role in Indonesia as a source of income for the State Budget and energy sources, in particular, Oil Fuel, to drive various sectors of life throughout Indonesia. Therefore, various efforts are made by the government so that sectoral consumption is maintained.

\section{CONCLUSION}

Based on the discussion, the research findings refer to the three points including: 1.) ICOR value from 2018 to 2020 shows an average value of 0.29 where it is impacted by changes in capital $(\Delta \mathrm{K})$ and changes in output $(\Delta Y)$ in each year, 2$)$ the food industry sector in Gorontalo Province has a sufficiently low ICOR value, a low ICOR value is claimed to be good as the economy runs with a high level of efficiency. While the chemical and pharmaceutical industry owns massive capital productivity, and the higher ICOR value indicates the use of capital-intensive technology. Also, the sectoral investment projection based on ICOR has led researchers to rank the top three sectors that will become the leading sectors in 2025 for Gorontalo investment projection that are food and plantation crops; trade and repair; and construction, and 3.) the government's policy to stay at home during the COVID-19 pandemic has changed people's consumption style significantly for basic household needs such as water, electricity, gas, food, and medicine.

\section{REFERENCE}

Artis, D., Syaparuddin, \& Nurhayati. (2015). Kajian ICOR Kabupaten Batanghari. Jurnal Paradigma Ekonomika, 10(01), 221-230.

Badan Koordinasi Penanaman Modal Provinsi Gorontalo. (2021). Realisasi Investasi Provinsi Gorontalo. Provinsi Gorontalo.

Bank Indonesia. (2021). Data Investasi Rekap Gorontalo. Gorontalo.

Bhinadi, A. (2003). Disparitas Pertumbuhan Ekonomi Jawa Dengan Luar Jawa. Jurnal Ekonomi Dan Studi Pembangunan, 8(1), 39-48.

BKPM Indonesia. (2020). Pengaruh Covid-19 terhadap Investasi di Indonesia Investasi Indonesia. Indonesia Investment Coordinating Board. Retrieved from https://www.investindonesia.go.id/ id/artikel-investasi/detail/pengaruh-covid-19-terhadap-investasi-di-indonesia

BPS Provinsi Gorontalo. (2020). Provinsi Gorontalo Dalam Angka 2020 (B. I. P. 
dan D. Statistik, ed.).

BPS Provinsi Gorontalo. (2021, February 26). PDRB ADHK Menurut Lapangan Usaha (Subsektor), 2010-2020. BPS Provinsi Gorontalo, pp. 3-4.

Dariyanto, A., \& Hafizrianda, Y. (2010). Model-Model Kuantitatif, Untuk perencanaan Pembangunan Ekonomi Daerah, Konsep dan Aplikasi. Jurnal Press, Kampus IPB Taman Kencana, 4(1).

Dewati, R., \& Saputro, W. A. (2020). Persepsi Konsumen Terhadap Pembelian Produk Herbal di Kabupaten Sukoharjo. Agrisaintifika Jurnal IImu-IImu Pertanian, 4(2).

Halim, A. (2004). Ekonomi Pembangun (Pertama, C). Sleman, Yogyakarta: Ekonisia.

Hapsari, L. A., Astuti, A. P., \& Praswati, A. N. (2020). Konsumsi Makanan dan Olahraga selama Pandemi Covid 19. The 12th University Research Colloqium 2020, 154-161. Retrieved from http://repository.urecol.org/index.php/ proceeding/article/view/1137

Hasan, W., \& Jumiyanti, K. R. (2021). Peta Kemampuan Keuangan Daerah. JRAK, 12(1), 38-52.

Irawan, Y. (2010). Analisis Incremental Capital Output Rasio di Provinsi Sumatera Utara. Ekonomi Dan Bisnis, 9(2). https://doi.org/1693-8852

Kunle, A., S.O., O., \& Oluwafolakemi, F. O. (2014). Impact of Foreign Direct Investment on Nigeria Economic Growth. International Journal of Academic Research in Business and Social Sciences, 4(8), 234-242.

Kuntara, T. (2016). Analisis Incremental Capital Output Ratio (ICOR) dan Pertumbuhan Ekonomi Provinsi di Pulau Jawa (Universitas Lampung). Retrieved from http://eprints.ums.ac.id/70834/11/ Naskah Publikasi-13ii.pdf

Kompas.com. (2020). Akibat Pandemi Covid-19, BKPM Koreksi Target Realisasi Investasi 2020. Kompas.Com. Retrieved from

LM, L. S. (2017). Analisis Investement Capital Output Ratio (ICOR) Dalam Rangka Proyeksi Kebutuhan Investasi Di Kabupaten Majalengka Tahun 20172019. IImiah Manajemen Dan Akuntansi (Maksi), 4(1). https://doi.org/2356-3923

Mahmud, M. F. (2008). Incremental Capital Output Ratio: Baromoter Efisiensi Perekonomian Indonesia. Ekonomi Bisnis, 13(1), 27-37. Retrieved from http://www.jstor.org/stable/25829927 Accessed:

Munifah, S. (2019). Analisis ICOR terhadap Efisiensi Pertumbuhan Ekonomi di Indonesia. Retrieved from https://www. google.com/url?sa=t\&rct=j\&q=\&esrc= s\&source $=$ web\&cd $=\& c a d=$ rja $\&$ uact $=8$ \&ved=2ahUKEwil_Zy887PsAhXZfH0 KHWcSALQQFjAAegQIBxAC\&url=h ttp $\% 3 \mathrm{~A} \% 2 \mathrm{~F} \% 2 \mathrm{Feprints.ums.ac.id \% 2}$ F70834\%2F11\%2FNaskah\%2520Pu blikasi-13ii.pdf\&usg=AOvVaw2BbF2 ym8auqPruZ3X_OH2

Permani, A. W. (2020). Korupsi Bukan Satu-satunya Faktor Penyebab Tidak Efisiennya Investasi di Indonesia Suara Surabaya. Suarasurabaya.Net. Retrieved from https://www.suarasurabaya.net/kelanakota/2020/korupsibukan-satu-satunya-faktor-penyebabtidak-efisiennya-investasi-di-indonesia/

Setiyanto, A. (2015). ICOR Sektor Pertanian sebagai Basis Arah Investasi dalam Pembangunan Pertanian Berbasis Kabupaten / Kota Di Indonesia ICOR of Agriculture Sector as a Base Direction of Regency / Municipality Agriculture Development in Indonesia. Analisis Kebijakan Pertanian, 13(1), 75-108. 
Susilowati, S. H., Hadi, P. U., Friyatno, S., Rachmat, M., Maulana, M., \& Azis, M. (2012). Estimasi Incremental Capital Ratio( ICOR ) Untuk Perencanaan Investasi dalam rangka Pembangunan Sektor Pertanian (Estimation of Incremental Capital Output Ratio ( ICOR ) for Investment Planning in the Agricultural Sector Development Framework). Agro Ekonomi, 30(2), 159-182.

Walters, A. A. (2016). Incremental CapitalOutput Ratios. The Economic Journal, 76(304), 818-822.

Widyastuti, N. L., \& Nugroho, H. (2020). Dampak Covid-19 terhadap Industri Minyak dan Gas Bumi : Rekomendasi Kebijakan untuk Indonesia Dampak Covid-19 terhadap Industri Minyak dan Gas Bumi : Rekomendasi Kebijakan untuk Indonesia. The Indonesian Journal of Development Planning, IV(2), 166-176. 